\title{
A randomized clinical trial of two single-dose treatments for paucibacillary leprosy
}

\author{
S. R. PATTYN*, P. GHYS $\dagger$, L. JANSSENS $\ddagger$, \\ K. TSHILUMBA $\dagger$, L. KUYKENS $\dagger$, N. KARIBUSHI \\ \& P. DENIS \\ *University of Antwerp and Institute of Tropical Medicine, Antwerp, \\ Belgium; †Damien Foundation, Kisangani, Zaïre; †Damien \\ Foundation, Musienene, Zaïre; §Damien Foundation, Lubumbashi, \\ Zaïre
}

Accepted for publication 20 September 1993

Summary We compared 2 single-dose regimens for the treatment of paucibacillary leprosy in a randomized clinical trial in Zaïre. The regimens were : C2 (rifampicin $40 \mathrm{mg} / \mathrm{kg}$ and $1200 \mathrm{mg}$ clofazimine once) and C4 (rifampicin $40 \mathrm{mg}$ / $\mathrm{kg}$, clofazimine $100 \mathrm{mg}$, DDS $100 \mathrm{mg}$ and ethionamide $500 \mathrm{mg}$ once). An analysis of the results of patients enrolled between May 1987 and December 1988, with a maximum follow-up of 4 years, is presented. A total of 622 patients were enrolled and 14 paucibacillary and 1 multibacillary relapses occurred. The overall paucibacillary relapse rate was 2.4 per 100 person years. This relapse rate was higher for older patients as well as for patients with 3 or more lesions. The probability of cure at 3 years is 0.816 for $\mathrm{C} 2$ and 0.823 for $\mathrm{C} 4$, the difference not being statistically significant. The probability of cure at 3 years with either regimen is higher for patients with 1 or 2 lesions $(0 \cdot 872)$ than for patients with 3 or more lesions $(0 \cdot 787)$, and it is higher for patients with a bacterial index of $0(0.831)$ than for patients with a bacterial index of $1(0 \cdot 699)$. These results are compared to other studies. We also discuss the potential of single-dose treatment regimens for paucibacillary leprosy.

\section{Introduction}

In a previous study on the treatment of paucibacillary (PB) leprosy it was discovered that a single dose of rifampicin (RMP) $40 \mathrm{mg} / \mathrm{kg}$ bodyweight resulted in unacceptable cure and relapse rates in patients with $\mathrm{a} B \mathrm{BI}=1$ and was therefore unsuited for wide-scale application. ${ }^{1}$

We report here an analysis of a randomized clinical trial of 2 single-dose treatments for PB leprosy. The objective of the trial was to evaluate, in terms of probability of cure, relapse rate, and development of disabilities 2 single-dose regimens for the treatment of PB leprosy. An additional objective was to assess the influence of other factors (age, sex, 
histological type, bacterial index (BI) and number of lesions) on probability of cure, relapse rate and development of disabilities.

\section{Patients and methods}

The trial was approved by the authorities within the Ministry of Health of the Republic of Zaïre and conducted under the auspices of the Bureau National de la Lèpre. Patients were recruited from 11 leprosy treatment units in 3 regions in Zaïre between May 1987 and December 1988. All of these units have outreach activities. Staff at these units are paramedical workers with extensive experience in leprosy control. They are supervised on a regular basis (at least twice a year) by 1 medical officer per region. Patients presenting to these units' clinics were diagnosed and classified on clinical grounds. Only new patients were eligible for inclusion in the study. A slit-skin smear was obtained from at least 3 sites and examined at the unit's laboratory facilities. Patients diagnosed as having PB leprosy were fully informed on the treatment to be received. After the patient's consent, a 6-mm or, rarely, a 4-mm punch biopsy was taken from the most active looking lesion. Some patients refused a biopsy, including the patients who had a single facial lesion. Skin biopsies were fixed either in a $10 \%$ formalin solution or in FMA fixative ${ }^{2}$ and sent to the Leprosy Laboratory, Institute of Tropical Medicine, Antwerp, Belgium, together with a clinical information form. During the initial clinical examination, each patient's skin lesions were indicated on a body chart. The disability grading was according to the recommendations of the WHO's expert committee in $1977^{3}$ using a 4-grade system. Development of disabilities was analysed for those who were free of disability at enrollment. The patients' ages were either taken from their identity cards or estimated.

The regime the patients undertook was chosen randomly from either treatment. If there was a serious clinical doubt as to whether the patient really suffered from PB leprosy, we waited for the result of a skin biopsy and the patient was randomized when he or she represented to the clinic af ter the reception of the histopathology result.

The 2 single-dose treatment regimens (adult doses) were:

C2: $40 \mathrm{mg} / \mathrm{kg} \mathrm{RMP}$ and $1200 \mathrm{mg}$ clofazimine (CLO).

C4: $40 \mathrm{mg} / \mathrm{kg} \mathrm{RMP,} 100 \mathrm{mg}$ CLO, $100 \mathrm{mg}$ DDS and $500 \mathrm{mg}$ ethionamide (ETH).

All drugs were swallowed in the presence of the staff.

Patients were entered in the study if both the following conditions were fulfilled: a BI of no more than 1 at any site either in the slit-skin smear or the sections for histopathology, and a histopathological pattern of either TT or BT leprosy. ${ }^{4}$

All histological preparations were examined by a single examiner (SRP). Indeterminate cases were excluded, because there is considerable controversy concerning their significance. ${ }^{5}$

Data are available for up to 4 years for patients enrolled during 1987 but only for up to 3 years for the majority of patients enrolled during 1988. A follow-up examination was done 1 year after the date of treatment, consisting of the same procedures as the initial examination, with the exception of the taking of a skin smear (unless clinically indicated) and a biopsy, as previous research had shown that only a small proportion (18-39\%) of patients would have achieved histopathological cure 1 year after the start of treatment. ${ }^{6}$ At 2 years after the treatment, a biopsy was included in the follow-up examination. As a 
rule, follow-up biopsies were taken from the same lesion from which the initial biopsy was taken. However, if this lesion had disappeared at follow-up, and other lesions were still present or new lesions had appeared, the follow-up biopsy was taken from these lesions. If histology had shown no evidence of leprosy at 2 years, no biopsy was taken at 3 years unless there were clinical reasons for doing so, e.g. reappearance of old lesions or appearance of new lesions. If, on the other hand, there were histological signs of leprosy at 2 years, a biopsy was taken at 3 years. Similar rules were applied for the follow-up examination at 4 years. The criterium for cure was the disappearance of histological lesions at year 2 or 3 if the patient did not have a 'no leprosy' biopsy at year 2 .

PB relapses are defined as patients who show histological evidence of leprosy after having shown no histological evidence of leprosy in a previous biopsy. As the first followup biopsy is taken at 2 years, a patient can only be at risk of PB relapse from year 2 onwards. Multibacillary (MB) relapses are defined as patients who show a BT of 2 or more in either skin smear or sections for histopathology at any time during the follow-up period.

Statistical analysis was performed using survival analysis techniques: the KaplanMeyer estimate of survival, Peto's formula for calculation of $95 \%$ confidence intervals and the logrank test for comparison of the survival function. ${ }^{7,8}$ The $\chi^{2}$ test with continuity correction was used for the comparison of proportions. Confidence intervals for single proportions were based on the normal approximation to the binomial distribution. Relapse rates were calculated using as a denominator the person years since treatment. Significance testing and confidence intervals for relapse rates were based on the normal approximation to the Poisson distribution. The confidence interval for a rate of 0 was taken from Tabulae Scientificae. ${ }^{9}$ Relative risks and $95 \%$ confidence intervals for development of disabilities were calculated with Epi-Info.

\section{Results}

Randomization resulted in 317 patients receiving $\mathrm{C} 2$ and 305 patients receiving $\mathrm{C} 4$. Their characteristics are shown in Table 1.

The patients are approximately equally distributed over both regimens in the number of skin lesions ( $<3$ versus $\geqslant 3$ ), histopathological classification (BT versus TT), BI as found in the tissue sections ( 1 versus 0 ), age and sex. Age is unknown for 173 patients $(28 \%)$, as some of the participating units failed to communicate this information.

A total of 8 patients died before the projected follow-up examination at 2 years from causes unrelated to leprosy. A total number of 187 (30\%) patients have so far not been assessed and are therefore considered as lost to follow-up. Tables 2 and 3 give their characteristics at intake, and according to treatment regimen, respectively. There is no difference in losses to follow-up between both treatment regimens. Patients aged $0-39$ are more likely to be lost to follow-up (33\%) than patients aged 40-79 (22\%): 0.05 > p $>0.025$.

Estimates of the probability of cure at 2 and 3 years of follow-up are given in Table 3 for both regimens. A Kaplan-Meyer estimate of noncure at 3 years was calculated assuming that patients who were not assessed at 2 years (but were assessed at 3 years) had the same probability of non-cure at 2 years as those patients who were assessed at both 2 and 3 years. The difference in probability of cure between $\mathrm{C} 2$ and $\mathrm{C} 4$ is not significant ( $\log$ rank test $=0 \cdot 24$ and $p>0 \cdot 5)$. 
Table 1. Distribution of patients according to treatment regimen

\begin{tabular}{|c|c|c|c|c|}
\hline & \multicolumn{2}{|c|}{ Regimen C2 } & \multicolumn{2}{|c|}{ Regimen C4 } \\
\hline & $\mathrm{N}=317$ & $(\%)$ & $\mathrm{N}=305$ & $(\%)$ \\
\hline \multicolumn{5}{|l|}{ Sex } \\
\hline male & 144 & $(45 \cdot 4)$ & 118 & $(38 \cdot 7)$ \\
\hline female & 170 & $(53 \cdot 6)$ & 184 & $(60 \cdot 3)$ \\
\hline unknown & 3 & $(0 \cdot 9)$ & 3 & $(1 \cdot 0)$ \\
\hline \multicolumn{5}{|l|}{ Age group } \\
\hline $0-19$ & 55 & $(17 \cdot 4)$ & 41 & $(13 \cdot 4)$ \\
\hline $20-39$ & 64 & $(20 \cdot 2)$ & 64 & $(21 \cdot 0)$ \\
\hline $40-59$ & 96 & $(30 \cdot 3)$ & 86 & $(28 \cdot 2)$ \\
\hline $60-79$ & 22 & $(6.9)$ & 21 & $(6 \cdot 9)$ \\
\hline unknown & 80 & $(25 \cdot 2)$ & 93 & $(30 \cdot 5)$ \\
\hline \multicolumn{5}{|c|}{ Number of skin lesions } \\
\hline 1 or 2 & 136 & $(42 \cdot 9)$ & 129 & $(42 \cdot 3)$ \\
\hline 3 or more & 181 & $(57 \cdot 1)$ & 176 & $(57 \cdot 7)$ \\
\hline \multicolumn{5}{|c|}{ Bacterial index } \\
\hline 0 & 296 & $(93 \cdot 4)$ & 283 & $(92 \cdot 8)$ \\
\hline 1 & 21 & $(6 \cdot 6)$ & 22 & $(7 \cdot 2)$ \\
\hline \multicolumn{5}{|c|}{ Histopathological classification } \\
\hline BT & 287 & $(90 \cdot 5)$ & 284 & $(93 \cdot 1)$ \\
\hline TT & 30 & $(9 \cdot 5)$ & 21 & $(6.9)$ \\
\hline
\end{tabular}

Disability scores for $\mathrm{C} 2$ and $\mathrm{C} 4$ were compared for 6 sites (left and right eyes, hands and feet) and no significant differences were observed, either between the 2 regimens or between different follow-up times.

The overall probability of cure for patients treated with either C2 or C4 is $0.723(95 \%$ CI: $0.701-0.746)$ at 2 years while it is $0.820(95 \%$ CI: $0.784-0.856)$ at 3 years. No differences in probability of cure were observed according to age group $\left(\log\right.$ rank $\chi^{2}=0 \cdot 27$ and $p>0 \cdot 5$ for $0-39$ vs $40-79$ years of age) or according to sex (log rank $\chi^{2}=1 \cdot 10$ and $p>0 \cdot 25)$. Table 4 gives the estimates of the probability of cure with $95 \%$ confidence intervals at 2 and 3 years according to histopathological classification, number of lesions and BI. Patients with BT leprosy have a smaller probability $(81 \%)$ of being cured at 3 years than have TT patients $(91 \%)$, but the observed difference is not significant $(p>0 \cdot 1)$. Patients with $\geqslant 3$ skin lesions have a smaller probability $(79 \%)$ of being cured at 3 years than have patients with $<3$ skin lesions $(87 \%)$. The observed difference is significant at the $90 \%$ level but not at the $95 \%$ level. The log rank test $\chi^{2}$ is 3.82 resulting in $0 \cdot 1>p>0 \cdot 05$. Finally patients with a $\mathrm{BI}=1$ have a smaller probability $(70 \%)$ of being cured at 3 years than have patients with a $\mathrm{BI}=0$ as found in the tissue sections $(83 \%)$. This difference is significant at the $95 \%$ level. (The log rank test $\chi^{2}$ is 4.15 and $0.05>p>0.025$.)

A boy who was 13 years old on enrollment as a patient in 1988 experienced a relapse of MB leprosy. He had an initial negative skin smear, a histopathological pattern of BT leprosy with a $\mathrm{BI}=0$, had more than 3 lesions and received the $\mathrm{C} 4$ regimen. Relapse was diagnosed 25 months after receiving treatment; histopathology showed a pattern of BB with a $\mathrm{BI}=3$; the skin smear result was $4 / 4 / 1$. The patient had been diagnosed as having 
Table 2. Characteristics at intake of patients lost to follow-up

\begin{tabular}{|c|c|c|}
\hline & \multicolumn{2}{|c|}{ Patients lost to follow up } \\
\hline & $\mathrm{N}$ & $(\%)$ of total \\
\hline \multicolumn{3}{|l|}{ Regimen } \\
\hline $\mathrm{C} 2$ & 94 & $(30)$ \\
\hline $\mathrm{C} 4$ & 93 & $(30)$ \\
\hline \multicolumn{3}{|l|}{ Age group } \\
\hline $0-19$ & 33 & (34) \\
\hline $20-39$ & 41 & (32) \\
\hline $40-59$ & 38 & (21) \\
\hline $60-79$ & 12 & (28) \\
\hline unknown & 63 & (36) \\
\hline \multicolumn{3}{|l|}{ Sex } \\
\hline male & 83 & $(32)$ \\
\hline female & 99 & (28) \\
\hline unknown & 5 & \\
\hline \multicolumn{3}{|c|}{ Histopathological classification } \\
\hline BT & 171 & (30) \\
\hline TT & 16 & (31) \\
\hline \multicolumn{3}{|c|}{ Bacterial index } \\
\hline 0 & 180 & $(31)$ \\
\hline 1 & 7 & (16) \\
\hline \multicolumn{3}{|c|}{ Number of skin lesions } \\
\hline 1 or 2 & 91 & (34) \\
\hline 3 or more & 96 & (27) \\
\hline
\end{tabular}

between 50 and 100 flat, hypopigmented, ill-defined skin lesions. The clinical picture was obscured by onchocerciasis lesions. The earlobes were possibly enlarged. Unfortunately, another skin smear was not taken af ter this smear proved negative. The initial skin biopsy had been taken from a large lesion on the thigh. During the follow-up examination at 1 year, all lesions attributable to leprosy had apparently disappeared, while there were still onchocerciasis lesions. During the follow-up examination at 2 years, multiple small lesions were present on the trunk, the back, the upper arms and the face; the earlobes were clearly enlarged with formation of nodules. Chemotherapy for MB leprosy was started as soon as the diagnosis was made.

Paucibacillary relapses occurred in 14 patients: their characteristics as well as an estimate of the relapse rate per 100 person years (PY) at risk are listed in Table 5.

The overall relapse rate (for both C2 and C4) was $2 \cdot 4$ per 100 PY (95\% CI: $1 \cdot 1-3 \cdot 7)$. The relapse rate was not significantly different between regimens $\mathrm{C} 2$ and $\mathrm{C} 4(3 \cdot 3$ and $1 \cdot 6$ respectively per $100 \mathrm{PY})$, between males and females ( 2.0 and 2.7 respectively per $100 \mathrm{PY})$, between BT and TT histopathological classification ( $2 \cdot 6$ and $0 \cdot 0$ respectively per $100 \mathrm{PY})$ nor between $\mathrm{BI}=1$ and $\mathrm{BI}=0$ (5.9 and $2 \cdot 2$ respectively per $100 \mathrm{PY})$. There was, however, a significant difference in relapse rate between age groups: patients aged $0-39$ had a relapse rate of 0.5 per $100 \mathrm{PY}$ while patients aged $40-79$ had a relapse rate of 4.8 per $100 \mathrm{PY}$ $(z=2 \cdot 47$; two-tailed $p=0 \cdot 014)$. Between patients with 1 or 2 lesions (relapse rate of 0.4 per 
Table 3. Characteristics of patients lost to follow-up, according to treatment regimen

\begin{tabular}{|c|c|c|c|c|}
\hline & \multicolumn{2}{|c|}{ Regimen $\mathrm{C} 2$} & \multicolumn{2}{|c|}{ Regimen C4 } \\
\hline & $\mathrm{N}=94$ & $(\%)$ & $N=93$ & $(\%)$ \\
\hline \multicolumn{5}{|l|}{ Sex } \\
\hline male & 41 & (44) & 42 & $(45)$ \\
\hline female & 51 & (54) & 48 & $(52)$ \\
\hline unknown & 2 & (2) & 3 & (3) \\
\hline \multicolumn{5}{|l|}{ Age group } \\
\hline $0-19$ & 22 & (23) & 11 & (12) \\
\hline $20-39$ & 18 & (19) & 23 & (25) \\
\hline $40-59$ & 19 & (20) & 19 & $(20)$ \\
\hline $60-79$ & 5 & (5) & 7 & (8) \\
\hline unknown & 30 & (32) & 33 & (36) \\
\hline \multicolumn{5}{|c|}{ Number of skin lesions } \\
\hline 1 or 2 & 50 & $(53)$ & 41 & (44) \\
\hline 3 or more & 44 & (47) & 52 & $(56)$ \\
\hline \multicolumn{5}{|c|}{ Bacterial index } \\
\hline 0 & 91 & $(97)$ & 89 & $(96)$ \\
\hline 1 & 3 & (3) & 4 & (4) \\
\hline \multicolumn{5}{|c|}{ Histopathological classification } \\
\hline BT & 87 & $(93)$ & 84 & $(90)$ \\
\hline TT & 7 & (7) & 9 & $(10)$ \\
\hline
\end{tabular}

Table 4. Probabilities of cure at 2 and 3 years according to treatment regimen, to histopathological classification, number of skin lesions and bacterial index

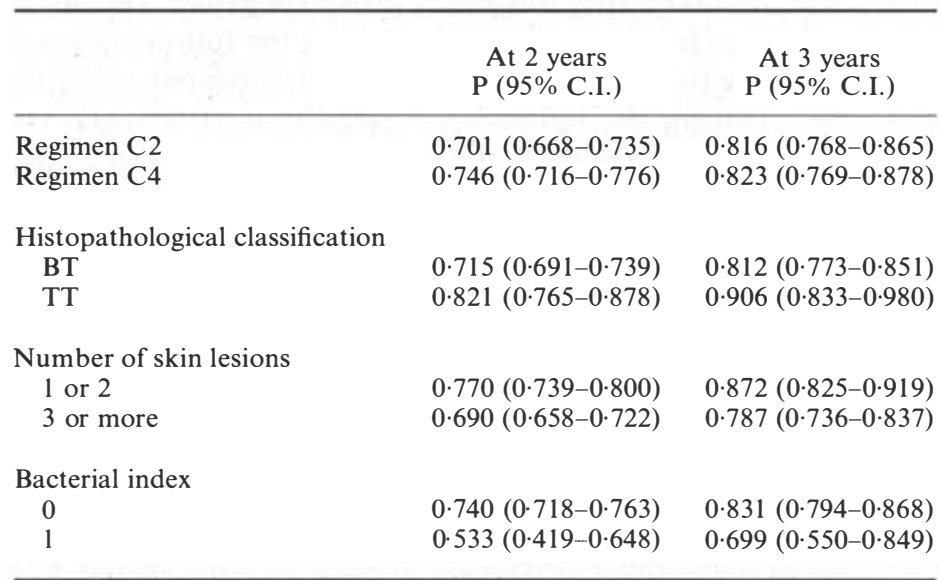


Table 5. Characteristics of 14 paucibacillary relapse cases and estimated relapse rates per $100 \mathrm{PY}$

\begin{tabular}{|c|c|c|c|}
\hline & $\mathrm{N}$ & Total & $\begin{array}{l}\text { Relapse rate } \\
\text { per } 100 \mathrm{PY}\end{array}$ \\
\hline All & 15 & 582 & $2 \cdot 5(1 \cdot 3-4 \cdot 0)$ \\
\hline \multicolumn{4}{|l|}{ Regimen } \\
\hline $\mathrm{C} 2$ & 9 & 276 & $3 \cdot 3(1 \cdot 1-5 \cdot 4)$ \\
\hline $\mathrm{C} 4$ & 6 & 306 & $1 \cdot 9(0 \cdot 7-4 \cdot 0)$ \\
\hline \multicolumn{4}{|l|}{ Age group } \\
\hline $0-39$ & -2 & 217 & $0 \cdot 9(0 \cdot 1-3 \cdot 5)$ \\
\hline $40-79$ & 10 & 209 & $4 \cdot 8(1 \cdot 8-7 \cdot 8)$ \\
\hline unknown & 3 & 156 & $1 \cdot 9(0 \cdot 0-4 \cdot 1)$ \\
\hline \multicolumn{4}{|l|}{ Sex } \\
\hline male & 6 & 252 & $2 \cdot 3(0 \cdot 8-4 \cdot 9)$ \\
\hline female & 9 & 330 & $2 \cdot 7(0 \cdot 9-4 \cdot 5)$ \\
\hline \multicolumn{4}{|c|}{ Histopathological classification } \\
\hline TT & 0 & 41 & $0 \cdot 0(0 \cdot 0-9 \cdot 0)$ \\
\hline BT & 15 & 541 & $2 \cdot 7(1 \cdot 7-4 \cdot 9)$ \\
\hline \multicolumn{4}{|c|}{ Bacterial index } \\
\hline 0 & 13 & 548 & $2 \cdot 3(1 \cdot 2-4 \cdot 0)$ \\
\hline 1 & 2 & 34 & $5.9(0 \cdot 0-14 \cdot 0)$ \\
\hline \multicolumn{4}{|c|}{ Number of skin lesions } \\
\hline 1 or 2 & 1 & 273 & $0 \cdot 4(0 \cdot 0-1 \cdot 1)$ \\
\hline 3 or more & 14 & 309 & $4 \cdot 5(2 \cdot 4-7 \cdot 6)$ \\
\hline
\end{tabular}

100 PY) and patients with 3 or more lesions (relapse rate of $4 \cdot 2$ per $100 \mathrm{PY}$ ), the difference in relapse rate was also significant $(z=2 \cdot 71$; two-tailed $p=0 \cdot 007)$.

Patients who received the $\mathrm{C} 4$ regimen were 1.6 times more likely to develop disabilities as compared to those on $\mathrm{C} 2$, but this difference was not significant $(p=0 \cdot 2)$ (Table 6$)$.

Patients 40-79 years old were 5 times more likely to develop disabilities as were patients aged $0-39(p=0 \cdot 001)$. Patients with 1 or 2 lesions were far less likely to develop disabilities as were patients with 3 or more lesions $(\mathrm{RR}=6 \cdot 9 ; p=0 \cdot 00002)$. None of the 26 TT patients developed disabilities, while $12 \%$ of 304 BT patients did; the difference is not statistically significant, however $(p=0 \cdot 1)$. This is in line with observations made in previous studies. ${ }^{1,6,14}$

\section{Discussion}

\section{CHOICE OF THE STUDY REGIMENS}

The choice of the 2 regimens was based on the previous experience in the same collaborating units with a single-dose regimen consisting only of a single dose of $40 \mathrm{mg} / \mathrm{kg}$ rifampicin ${ }^{1}$ : patients who received this regimen were estimated to reach histological cure at 2 years in $53-54 \%$ of patients and at 3 years in $65-85 \%$ of patients.

It is obvious that if a single-dose regimen is to be effective, (an)other drug(s) should be 
Table 6. Development of disabilities in initially disability-free patients

\begin{tabular}{|c|c|c|c|c|c|}
\hline & \multirow[b]{2}{*}{$\mathrm{N}$} & \multicolumn{2}{|c|}{ Disabilities at FU } & \multirow[b]{2}{*}{$\mathrm{RR}$} & \multirow[b]{2}{*}{$(95 \% \mathrm{CI})$} \\
\hline & & $\mathrm{N}$ & $(\%)$ & & \\
\hline Overall & 330 & 37 & $(11 \cdot 2)$ & & \\
\hline \multicolumn{6}{|l|}{ Regimen } \\
\hline $\mathrm{C} 2$ & 173 & 15 & $(8 \cdot 7)$ & \multicolumn{2}{|c|}{ Ref erence } \\
\hline $\mathrm{C} 4$ & 157 & 22 & $(14 \cdot 0)$ & 1.6 & $(0 \cdot 9-3 \cdot 0)$ \\
\hline \multicolumn{6}{|l|}{ Sex } \\
\hline female & 200 & 21 & $(10 \cdot 5)$ & \multicolumn{2}{|r|}{ Reference } \\
\hline male & 129 & 16 & $(12 \cdot 4)$ & $1 \cdot 2$ & $(0 \cdot 6-2 \cdot 2)$ \\
\hline \multicolumn{6}{|l|}{ Age group } \\
\hline $0-39$ & 121 & 4 & $(3 \cdot 3)$ & \multicolumn{2}{|r|}{ Ref erence } \\
\hline $40-79$ & 120 & 20 & $(16 \cdot 7)$ & $5 \cdot 0$ & $(1 \cdot 8-14)$ \\
\hline \multicolumn{6}{|c|}{ Number of skin lesions } \\
\hline 1 or 2 & 150 & 4 & $(2 \cdot 7)$ & \multicolumn{2}{|c|}{ Reference } \\
\hline 3 or more & 180 & 33 & $(18 \cdot 3)$ & $6 \cdot 9$ & $(2 \cdot 5-19)$ \\
\hline \multicolumn{6}{|c|}{ Bacterial index } \\
\hline 0 & 307 & 32 & $(10 \cdot 4)$ & \multicolumn{2}{|r|}{ Reference } \\
\hline 1 & 23 & 5 & $(21 \cdot 7)$ & $2 \cdot 1$ & $(0 \cdot 9-4 \cdot 8)$ \\
\hline \multicolumn{6}{|c|}{ Histopathological classification } \\
\hline TT & 26 & 0 & $(0 \cdot 0)$ & \multicolumn{2}{|r|}{ Ref erence } \\
\hline BT & 304 & 37 & $(12 \cdot 2)$ & $\infty$ & $*$ \\
\hline
\end{tabular}

added to the RMP. A study at the Institut Marchoux in Bamako in multibacillary patients found monthly doses of $1200 \mathrm{mg}$ CLO to be quite effective in inhibiting the growth of Mycobacterium leprae. ${ }^{10}$

The $\mathrm{C} 2$ regimen, consisting of $40 \mathrm{mg} / \mathrm{kg} \mathrm{RMP}$ and $1200 \mathrm{mg}$ of CLO, was therefore tried. The control regimen should ideally have been either the previously studied regimen (in order to show that the addition of $1200 \mathrm{mg}$ CLO does or does not have an effect) or the MDT regimen as recommended by the WHO study group in $1982 .^{12}$ The WHO recommended regimen was rejected because of the expected low accessibility of the new patients; indeed the bulk of new patients were expected to come from remote clinics, where a monthly visit by the units' staff would not be possible. The previously-studied regimen of $40 \mathrm{mg} / \mathrm{kg} \mathrm{RMP}$ as a single dose should therefore have been the control regimen in this setting. There was, however, opposition f rom some of the staff of the collaborating units to this, because there was already some evidence that this regimen was slightly less effective when compared to the regimen consisting of $1500 \mathrm{mg}$ rifampicin once followed by 1 year of daily DDS. ${ }^{9}$ On the other hand, the advantage of a single-dose regimen was recognized by all the staff. The $\mathrm{C} 4$ regimen was therefore proposed as it is reported here.

\section{RELAPSE RATE}

As we stressed in our previous publications ${ }^{1,6,15}$ a major difficulty in evaluating therapeutic studies in PB leprosy is to differentiate relapses from reversal reactions. In all 
Table 7. Probability of cure at 3 years after start of treatment for various treatment regimens for PB leprosy

Regimen

RMP $1500 \mathrm{mg}$ once + DDS $100 \mathrm{mg}$ daily for 1-year [1]

idem [6]

RMP $40 \mathrm{mg} / \mathrm{kg}$ once [1]

DDS $100 \mathrm{mg}$ daily for 3 years [14]

RMP 8 weekly doses of $900 \mathrm{mg}$ [14]

RMP 10 weekly doses of $900 \mathrm{mg}$ [6]

RMP 10 weekly doses of $600 \mathrm{mg}$ [6]

RMP 12 weekly doses of $900 \mathrm{mg}$ [14]

RMP $600 \mathrm{mg}$ daily + DDS $100 \mathrm{mg}$ daily for 6 days [14]

RMP $600 \mathrm{mg}$ monthly + DDS $100 \mathrm{mg}$ daily for 6 months [14]

RMP $40 \mathrm{mg} / \mathrm{kg}$ + clofazimine $1200 \mathrm{mg}$ once (C2)

RMP $40 \mathrm{mg} / \mathrm{g}$ + clof azimine $100 \mathrm{mg}$ + DDS $100 \mathrm{mg}$ + ethionamide $500 \mathrm{mg}$ once (C4)
Probability of cure at 3 years from start of treatment $(\%)$

our previous studies as well as in this one, we have chosen for 'the worst hypothesis' and counted all reappearances of histopathological lesions as relapses, although at least some of these could be reversal reactions. Furthermore, the present study was interrupted at an early stage, with a mean follow-up of 1.5 years, which may be too early to detect all relapses.

In addition to the $14 \mathrm{~PB}$ relapses, a single $\mathrm{MB}$ relapse occurred. It seems possible that the patient already had features of MB leprosy on enrollment in 1988. Chopra et al. observed $4 \mathrm{MB}$ relapses among 11,095 PB patients released from control. ${ }^{11}$ Both Boerrigter et al. ${ }^{13}$

follow-up studies of PB leprosy patients who received either the WHO recommended regimen or a modification of this.

The PB relapse rate was higher for C2 (3.3 per 100 PY; 95\% CI: $1 \cdot 1-5 \cdot 4)$ when

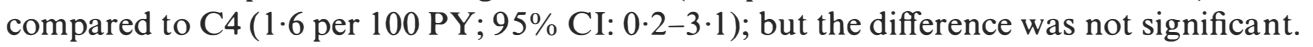
It may be concluded that the addition of a high dose $(1200 \mathrm{mg})$ of CLO to a single high dose $(40 \mathrm{mg} / \mathrm{kg})$ of RMP is no better in terms of relapse rate than the addition of conventional single doses of CLO (100 mg), DDS (100 mg) and ethionamide (500 $\mathrm{mg})$ to the same single high dose of RMP. Boerrigter et al. ${ }^{13}$

PY (95\% CI: 3.4-11.4) for WHO-MDT and reviewed reported relapse rates from other publications, ranging from 7 to 120 per $1000 \mathrm{PY}$. The overall relapse in the present study, 24 per 1000 PY (95\% CI: 11-37) is within that range, but formal comparison is unjustified as widely different methodologies were used in these studies. In our earlier studies, using the same methodology, relapse rates of $0 \cdot 0$ to 1.0 per $100 \mathrm{PY}^{1}$ and 1.3 to $5 \cdot 2$ per $100 \mathrm{PY}^{9}$ for a single high dose of RMP followed by 1 year of daily dapsone, a relapse rate of 2.0 to 2.4 per $100 \mathrm{PY}^{9}$ for 10 weekly doses of RMP and a relapse rate of 1.3 to 3.6 per $100 \mathrm{PY}^{1}$ for a single high dose of RMP were reported.

\section{PROBABILITY OF CURE}

The probability of cure at 3 years is $81 \cdot 6 \%$ for $\mathrm{C} 2$ and $82 \cdot 3 \%$ for $\mathrm{C} 4$, the difference between both regimens not being significant. Even though no formal statistical comparison is possible with other regimens, these figures do compare favourably to 9 other regimens which were studied with the same methodology $y^{1,6,15}$ as is shown in Table 7. 
The regimen recommended by the WHO Study Group, studied with the same methodology, yielded a probability of cure of $72 \%$ at 3 years. ${ }^{15}$

A recent study from India in patients with a single lesion, using similar methodology as we used in the present study, compared WHO/MDT to daily DDS: good or excellent results (as assessed by histopathology 2.5 years after starting therapy) were obtained in $80 \%$ of patients on WHO-MDT and in $91 \%$ of patients on daily DDS: the difference was not significant due to the small numbers of patients (25 and 23 , respectively). ${ }^{16}$ Our estimate of cure at 3 years for patients with 1 or 2 lesions, treated with either $\mathrm{C} 2$ or $\mathrm{C} 4$, was $87 \%$. Like the relapse rates, the probability of cure also varies with the immunological spectrum (Table 4): it was significantly higher for patients with 1 or 2 lesions (as compared to patients with 3 or more lesions) and patients with a $\mathrm{BI}=0$ (as compared to patients with a $\mathrm{BI}=1$ ); the difference between TT and BT was not significant.

\section{VALUE OF SKIN SMEAR RESULTS}

In its most recent report, the WHO Expert Committee recommended that 'Any case ... showing smear positivity will be classified as $\mathrm{MB}$ for purposes of multidrug therapy programmes', ${ }^{17}$ because it was realized that patients with a $\mathrm{BI}=1 \mathrm{did}$ not fare as well on the recommended regimen for PB leprosy as patients who had a $\mathrm{BI}=0$. We have made the same observation here for both regimens under study: the probability of cure at 3 years was $83 \%$ for patients with a $\mathrm{BI}=0$, while it was $70 \%$ for patients with a $\mathrm{BI}=1$ $(p<0 \cdot 05)$. However, these figures relate to the $\mathrm{BI}$ as determined in the histopathological sections. In our study only 1 patient out of 36 with a BI of 1 in the sections for histopathology for whom local skin smear results are available had a skin smear result of 1 , while the remaining 35 had a skin smear result of 0 . Histopathology is the more sensitive method as isolated bacilli are of ten situated in nerve twigs and therefore often missed when taking a skin smear.

\section{EFFECTIVENESS OF TREATMENT REGIMENS}

In terms of effectiveness, single-dose treatments for PB leprosy can be more or less effective than the WHO recommended regimen, depending on the accessibility of the patients. This can be illustrated with a numerical example looking at hypothetical probabilities of cure at 3 years (PC3). Let us assume $\mathrm{PC} 3$ to be $90 \%$ for regular patients on the WHO recommended regimen and $60 \%$ for irregular patients (including patients who collect just 1 out of the recommended 6 doses) on the WHO regimen. Let us assume PC3 to be $80 \%$ for all patients on a single-dose treatment (there can be no irregular patients with a single-dose regimen). The overall probability of cure at 3 years will depend on the proportions of patients who would be regular and irregular on the WHO recommended regimen. Let us assume that in an urban situation with good coverage by the drug delivery system, the proportions of regulars and irregulars are $90 \%$ and $10 \%$, respectively. Here $(90 \% \times 90 \%)+(10 \% \times 60 \%)=87 \%$ of patients would be cured at 3 years with the WHO regimen. Let us consider on the other hand a rural area which has difficult roads and a rainy season that blocks most of them for about 3 months every year, and assume that in this area the proportions of regulars and irregulars are $50 \%$ and $50 \%$, respectively. Here $(50 \% \times 90 \%)+(50 \% \times 60 \%)=75 \%$ of patients would be cured at 3 years with the WHO regimen. In both situations $80 \%$ of patients would be cured at 3 years with the single-dose 
regimen. In this hypothetical example, the WHO regimen would perform better than the single-dose regimen in an urban area, but the opposite would be true in a rural area. In an unpublished study of attendance to the WHO regimen in Kinshasa, Zaïre, 31 (22\%) out of 139 new PB patients were considered a treatment compliance risk and were therefore not given the WHO recommended regimen, while another 19 (14\%) were irregular (i.e. they did not take their 6 doses within 9 months). Irregularity is most probably worse in rural areas. Considerations of this kind should be borne in mind when interpreting cure rates and relapse rates from published studies, where patients who failed to compete the regimen are not included in the results. It is also likely that routine control programmes achieve lower compliance rates than research programmes do.

Finally a possible disadvantage of single-dose treatment might be that reversal reactions, particularly in areas that are inacessible, remain undetected and untreated, possibly causing severe disabilities.

\section{Conclusions and recommendations}

The most effective single-dose treatment for PB leprosy has still not been found. However, 3 classes of drugs have emerged as candidates for inclusion in multiple drug regimens for leprosy in recent years. Several fluoroquinolones have been found to be active against $M$. leprae ${ }^{18}$ : ofloxacin has been studied the most, but because the serum half-life is only 6 hours, ${ }^{19}$ while it is 11 hours for fleroxacin, ${ }^{20}$ fleroxacin may be a better option for a singledose regimen. Clarithromycin and minocycline are bactericidal against $M$. leprae and have extended serum half-lifes. ${ }^{21,22}$ These drugs could be particularly suited for combined therapy with rifampicin, as they all have a different mode of action.

\section{Acknowledgment}

The Leprosy Laboratory of the Institute of Tropical Medicine, Antwerp, Belgium, received financial support from the Damien Foundation, Brussels, Belgium and the European Economic Community.

\section{References}

1 Pattyn SR, Groenen G, Janssens L et al. A controlled therapeutic trial in paucibacillary leprosy comparing a single dose of rifampicin with a single dose of rifampicin followed by one year of daily dapsone. Lepr Rev, 1991; 62: 179-185.

2 Ridley DS. Skin biopsy in leprosy. Second Edition. Documenta Geigy, Basel, Switzerland, 1985.

3 WHO Expert Committee on leprosy. Fifth Report. Technical Report Series 607. WHO, Geneva, 1977.

4 Ridley DS, Jopling WH. A classification of leprosy according to immunity. A five-group system. Int $J$ Lepr, 1966; 34: 225-261.

${ }^{5}$ Pettit JHS. Should indeterminate leprosy ever be diagnosed? Int J Lepr, 1981; 49: 95-96.

${ }^{6}$ Pattyn SR, Groenen G, Bourland J et al. A controlled therapeutic trial in paucibacillary leprosy comparing a single dose of rifampicin followed by 1 year of daily dapsone with 10 weekly doses of rif ampicin. Lepr Rev, 1987; 58: 349-358.

7 Peto R, Pike HC, Armitage P et al. Design and analysis of randomized clinical trials requiring prolonged observation of each patient. II Analysis and examples. Br J Cancer, 1977; 35: 1-39.

8 Armitage P, Berry G. Statistical methods in medical research. Second Edition. Blackwell Scientific Publications, 1987. 
9 Tabulae Scientificae. Documenta Geigy. Seventh Edition. Diem K, Lentner C (eds). Basel: Ciba-Geigy, 1978.

${ }^{10}$ Annual activity report of the Institut Marchoux, Bamako, 1990.

${ }^{11}$ Chopra NK, Agarawal JS, Pandya PG. A study of relapse in a multidrug therapy project, Baroda District, India. Lepr Rev, 1990; 61: 157-162.

12 WHO Study Group. Chemotherapy of Leprosy for Control Programmes. Technical Report Series 675. WHO, Geneva, 1982.

${ }^{13}$ Boerrigter G, Ponnighaus JM, Fine PEM, Wilson RJ. Four-year follow-up results of a WHO recommended multiple-drug regimen in paucibacillary leprosy patients in Malawi. Int J Lepr, 1991; 59: 255-261.

${ }^{14}$ Katoch K, Ramu G, Ramathan U, Desikan KV. Comparison of three regimens containing rif ampicin for treatment of paucibacillary leprosy patients. Int J Lepr, 1987; 55: 1-8.

15 Pattyn SR, Husser JA, Baquillon G et al. Evaluation of five treatment regimens, using either dapsone monotherapy or several doses of rif ampicin in the treatment of paucibacillary leprosy. Lepr Rev, 1990; 61: $151-156$.

${ }^{16}$ Mathai R, George S, Jacob M. Fixed duration MDT in paucibacillary leprosy. Int J Lep, 1991; 59: 237-241.

17 WHO Expert Committee on Leprosy. Sixth Report. Technical Report Series 768. WHO, Geneva, 1988.

${ }^{18}$ Franzblau SG, White KE. Comparative in vitro activities of 20 fluoroquinolones against Mycobacterium leprae. Antimicrob Agents Chemother, 1990; 34: 229-231.

19 Wise R, Lister D, McNulty CAM et al. The comparative pharmacokinetics of five quinolones. $J$ Antimicrob Chemother, 1986; 18 Suppl. D: 71-81.

${ }^{20}$ De Lepeliere I, Van Hecken A, Verbesselt R et al. Comparative oral pharmacokinetics of fleroxacin and pefloxacin. J Antimicrob Chemother, 1988; 22: 197-202.

${ }^{21} \mathrm{Ji}$ B, Perani EG, Grosset JH. Effectiveness of Clarithromycin and Minocycline alone and in combination against experimental Mycobacterium leprae infection in mice. Antimicrob Agents Chemother, 1991; 35: 579-581.

22 Gelber RH. Activity of Minocycline in Mycobacterium leprae-infected mice. J Inf Dis, 1987; 156: 236-239. 


\title{
Un essai clinique randomizé de deux traitements par dose unique de la lèpre paucibacillaire
}

\author{
S. R. Pattyn, P. Ghys, L. Janssens, K. Tshilumba, L. Kuykens, \\ N. Karibushi et P. Denis
}

Résumé Nous avons comparé 2 posologies à dose unique pour le traitement de la lèpre paucibacillaire dans un essai clinique randomizé au Zaire. Les posologies étaient: C2 (rifampicine $40 \mathrm{mg} / \mathrm{kg}$ et clofazimine $1200 \mathrm{mg}$ en une prise) et C4 (rif ampicine $40 \mathrm{mg} / \mathrm{kg}$, clofazimine $100 \mathrm{mg}$, DDS $100 \mathrm{mg}$ et éthionamide $500 \mathrm{mg}$ en une prise). Nous présentons une analyse des résultats sur les malades enrôlés entre mai 1987 et décembre 1988, avec un suivi maximum de 4 ans. Un total de 622 malades ont été enrôlés et 14 rechutes paucibacillaires et une multibacillaire ont été observées. Le taux global de rechutes paucibacillaires a été de 2,4\% par 100 personnes/années. Ce taux de rechute a été plus élevé chez les patients les plus âgés ainsi que chez ceux qui avaient 3 lésions ou plus. La probabilité de guérison à 3 ans est 0,816 pour $\mathrm{C} 2$ et 0,823 pour $\mathrm{C} 4$ : la différence n'est pas significative. La probabilité de guérison à 3 ans avec les 2 posologies est plus forte pour les malades avec 1 ou 2 lésions $(0,872)$ que pour les malades avec 3 lésions ou plus $(0,787)$ et également pour les malades avec un index bactérien de $0(0,831)$ que pour les malades avec un index bactérien de $1(0,699)$. Ces résultats sont comparés à ceux d'autres études. Nous discutons aussi du potentiel d'un traitement à dose unique dans les lèpres paucibacillaires.

\section{Un ensayo clínico aleatorio de dos tratamientos de dósis única para la lepra paucibacilar}

\author{
S. R. Pattyn, P. Ghys, L. Janssens, K. Tshilumba, L. Kuykens, \\ N. KaRIBUShI Y P. DENIS
}

Resumen Comparamos dos regímenes de dósis única en el tratamiento de la lepra paucibacilar, en un ensayo clínico aleatorio en Zaire. Los regímenes fueron: C2 (rifampicina $40 \mathrm{mg} / \mathrm{kg}$ y $1200 \mathrm{mg}$ clofazimina una vez) y C4 (rif ampicina $40 \mathrm{mg} / \mathrm{kg}, 100 \mathrm{mg}$ clofazimina, $100 \mathrm{mg}$ DDS y $500 \mathrm{mg}$ etionamida una vez). Se presenta un análisis de los resultados de los pacientes registrados entre mayo 1987 y diciembre 1988, con un control posterior máximo de 4 años. Se registró un total de 622 pacientes y se observaron 14 relapsos 14 paucibacilares y 1 multibacilar. La tasa de relapso paucibacilar fue 2,4 por persona-año. Esta tasa de relapso fue más elevada en el caso de los pacientes más viejos, como también en el caso de pacientes con 3 o más lesiones. La probabilidad de una cura en 3 años es 0,816 en el caso de $\mathrm{C} 2$, y 0,823 en el de $\mathrm{C} 4$, y la diferencia no es significativa. La probabilidad de una cura en 3 años con cualquiera de los dos regímenes es mayor para los pacientes con 1 o 2 lesiones es $(0,872)$, que cuando hay 3 o más lesiones $(0,787)$, y es mayor para pacientes con un índice bacterial de $0(0,831)$ que para pacientes con un índice bacterial de $1(0,699)$. Se comparan estos resultados con los de otros estudios. También discutimos el potencial de regímenes de tratamiento con una dosis única en la lepra paucibacilar. 